\title{
SILDENAFIL: CAN CAUSE ACUTE ISCHAEMIC STROKE? A CASE REPORT
}

\author{
Zeynep ÖZÖZEN AYAS*, Kıyasettin ASİL*, Ayhan BÖLÜK* \\ *Sakarya University Faculty of Medicine, Department of Neurology, Sakarya, TURKEY \\ **Sakarya University Faculty of Medicine, Department of Radiology, Sakarya, TURKEY
}

\begin{abstract}
Sildenafil is an inhibitor of phosphodiesterase type-5 (PDE-5), is used for erectile dysfunction. There is not enough information about its effects on the central nervous system Headache, nasal congestion, facial flushing, nausea are the most common side effects. However, neurological complications such as third cranial nerve palsy, transient global amnesia, seizures, cerebral hemorrhage, and infarction are less commonly observed. We present a case of a 60-year-old man with acute ischaemic stroke, which we considered to be interrelated to sildenafil intake. Clinicians must be aware of the possibility of neurological side effects when the patient use sildenafil.
\end{abstract}

Key Words: Sildenafil, ischaemic stroke.

\section{SILLDENAFIL: AKUT İSKEMIK İNMEYE NEDEN OLABILİR Mİ? OLGU SUNUMU}

\section{ÖZET}

Sildenafil erektil disfonksiyon tedavisinde kullanılan bir fosfodiesteraz tip-5 (PDE-5) inhibitörüdür. Santral sinir sistemindeki etkilerine dair yeterli bilgi bulunmamaktadır. Başağrısı, nazal konjesyon, yüzde kızarıklık, bulantı sık görülen yan etkilerindendir. Bununla birlikte 3. kranial sinir felci, geçici global amnezi, nöbet, serebral kanama ve infarkt gibi nörolojik komplikasyonlar ise daha nadir görülmektedir. Biz 60 yaşındaki erkek hastada sildenafil alımı ile ilişkili olabileceğini düşündüğümüz akut iskemik inme olgusunu sunuyoruz. Bu yazıda klinisyenlerin, sildenafil kullanan hastalarda görülebilecek olası nörolojik yan etkiler konusunda dikkatli olmaları gerektiği vurgulanmıştır.

Anahtar Sözcükler: Sildenafil, iskemik strok.

\section{INTRODUCTION}

Sildenafil is an inhibitor of phosphodiesterase type-5 (PDE-5), is used for erectile dysfunction. There is not enough information about its effects on the central nervous system (CNS). Headache, nasal congestion, facial flushing, nausea are the most common side effects. However, neurological complications such as third cranial nerve palsy, transient global amnesia, seizures, cerebral hemorrhage, and infarction are less commonly observed. (1-2).

\section{CASE}

60-year-old, right-handed man who had no significant medical history, presented with rightsided hemiparesia and speech difficulty to the hospital. He was taking sildenafil regularly $25 \mathrm{mg}$ in a week for one year due to erectile dysfunction.
But he increased dosage to $75 \mathrm{mg}$ in a week for three weeks. The last night, he was healthy and had engaged in sexual intercourse. About 2 hours later he started to complain for weakness of rightsided and speech difficulty. His neurological examination had dysarthria, central facial paralysis, hemiparesia $(2+/ 5)$ and hemiparestesia, positive Babinski sign of the right-sided. Computed tomography (CT) of the brain showed no abnormality. His magnetic resonance imaging (MRI) showed acute infarct lesion in left medial temporal lobe (Figure 1 and 2). There was no abnormal result of his etiological investigations which included biochemical, coagulation, thrombotic laboratory tests. Electrocardiography, doppler ultrasound imaging of carotid arter and vertebral arteries were normal.

\footnotetext{
Corresponding author: Zeynep Özözen ayas, MD. Sakarya University Faculty of Medicine, Department of Neurology, Sakarya, Turkey.

Phone: +902648884051 E-mail: zozozen@hotmail.com

Received: 16.08.2014 Accepted: 13.11.2014

This article should be cited as following: Özözen Ayas Z, Asil K, Bölük A. Sildenafil: Can cause acute ischeamic stroke? A case report. Turkish Journal of Cerebrovascular Diseases 2015; 21 (3): 210-212. doi:10.5505/tbdhd.2015.08769.
} 


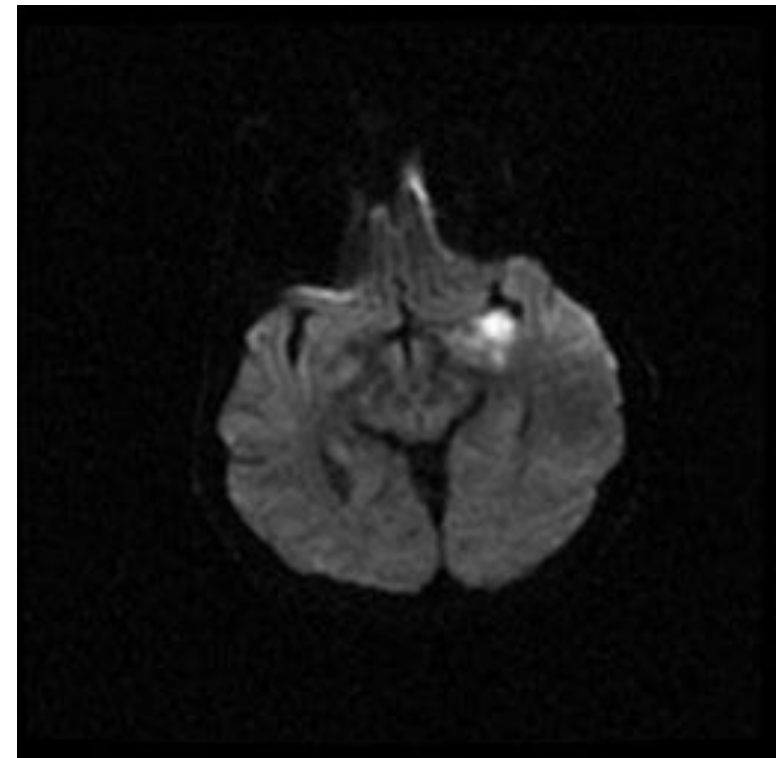

Figure 1. Hyperintensity in left medial temporal lobe consistent with acute ischemia on diffusion weighted imaging.

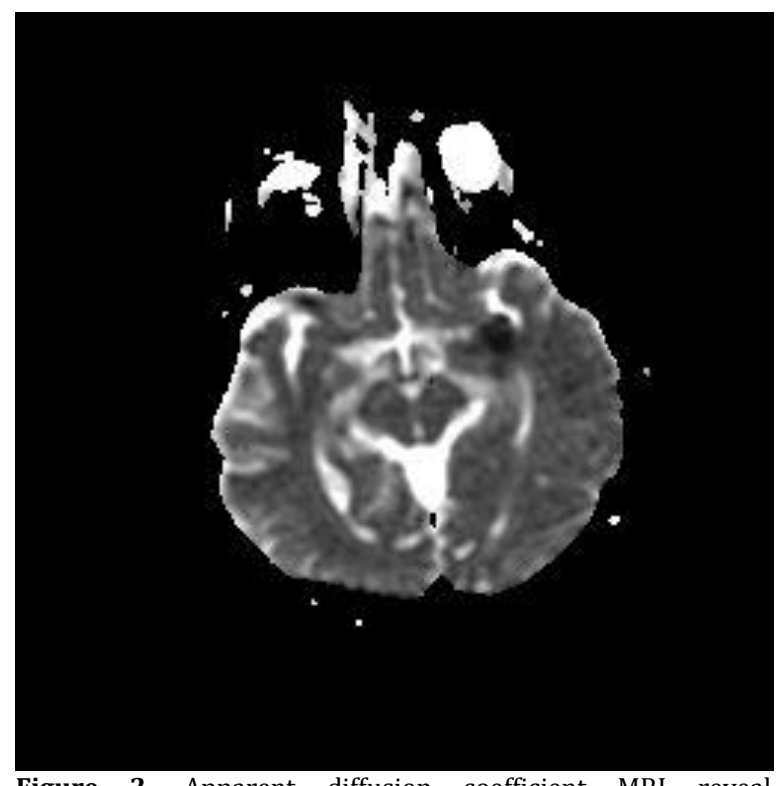

Figure 2. Apparent diffusion coefficient MRI reveal hypointensity which suggested acute infarct in left medial temporal lobe.

\section{DISCUSSION}

Sildenafil is an inhibitor of PDE-5, is used for erectile dysfunction. There is not enough information about its effects on the CNS, although it has been suggested that PDE-5 inhibitors might cross the blood-brain barrier. We present a case of a 60-year-old man with a cute ischaemic stroke, which we considered to be interrelated to sildenafil intake. PDE-5 inhibitors interact pharmacologically with nitric oxide (NO) and cyclic guanosine monophosphate (cGMP) signalling pathways. Sildenafil inhibits PDE-5 enzyme, that occurs high concentration of cGMP in tissues. The cGMP accumulates, causing smooth muscle relaxation and increased blood flow into the corpus cavernosum. Since PDE-5 is found in the brain as well as in the corpus cavernosum, PDE-5 inhibitors might exert side effects in the CNS by crossing the blood-brain barrier [3]. Sildenafil can cause ischaemic stroke by acutely lowering the blood pressure [4].

Some authors have suggested that there is increased risk of cerebrovascular events in association with sildenafil [5-6]. Mehdizahed et. al. reported a 63-year-old man who had visual field defect due to a hemorrhagic stroke in the occipital lobe after ingestion sildenafil [7]. An other report described a 52-year-old man with bilateral middle cerebral artery territory infarction associated with sildenafil use [1]. Savitz and Gandolfo et. al. reported the transient global amnesia after sildenafil use and Özcan et. al. reported transient ischaemic attack after sildenafil.

We think about that there was no distinct reason in our patient's stroke etiology except age, ischaemic stroke could be occured due to sildenafil using. Additionally to sildenafil vasodilatory effect in intracerebral arteries, increased sympathetic activity due to sexual intercourse provided increased of venous return may tigger an ischaemic stroke like as our patient. We cannot rule out the possibility of coincidentally events which were using sildenafil and ischaemic stroke. Age might be a single precipitating factor for stroke. Further studies are needed to either prove or disprove a causal relationship between sildenafil and stroke.

This case emphasizes that sildenafil might, in general, be capable of exerting side effects in the CNS. Clinicians must be aware of the possibility of neurological symptoms when the patient use sildenafil.

\section{REFERENCES}

1. Kim KK, Kim DG, Ku YH, et al. Bilateral cerebral hemispheric infarction associated with sildenafil citrate (Viagra) use. Eur J Neurol 2008; 15:306-308.

2. Savitz SA, Caplan LR. Transient global amnesia after sildenafil (Viagra) use. Neurolgy 2002;59:778. 
3. Schultheiss D, Müller SV, Nager W, et al. Central effects of sildenafil (Viagra) on auditary selective attention and verbal recognition memory in humans: a study with eventrelated brain potentials. World J Urol 2001;19:46-50.

4. Warlow C, van Gjin J, Dennis M, et al. Unusual causes of ischaemic stroke and transient ischaemic attack. In: Sugden $M$ ed. Stroke: Practical management. Third ed. Masschusetts 2008;382.

5. Morgan JC, Alhatou M, Oberlies J, et al. Transient ischemic attack and stroke associated with sildenafil (Viagra) use. Neurology 2001; 57:1730-1731.
6. Aydemir Özcan T, Meral H. Transient ischemic attack after intake of sildenafil. Türk Beyin Damar Hastalıkları Dergisi 2012;18;23-24.

7. Mehdizahed M, Hosseini H, Yazdchi T, et al. Visual field defect as a presenting sign for hemorrhagic stroke caused by sildenafil. Indian J Ophtalmol 2008; 56:159-160.

8. Ganolfo C, Sugo A, Del Sette M. Sildenafil and transient global amnesia. Neurol Sci 2003;24:145-146. 